\title{
Dampak Angka Harapan Hidup dan Kesempatan Kerja Terhadap Kemiskinan
}

\author{
Ecces: \\ Economics Social and Development Studies
}

Andi Lopa Ginting

\author{
Program Studi Ekonomi Pembangunan \\ Fakultas Ekonomi Universitas Terbuka \\ Jalan Cabe Raya, Pondok Cabe, Pamulang, Pd. Cabe Udik, \\ Kec. Pamulang, Kota Tangerang Selatan, Banten 15418 \\ Andi.lopaginting@ecampus.ut.ac.id
}

(Article history) Received: 2020-03-18, Revised: 2020-04-01, Accepted: 2020-06-14, Available online: 2020-06-24 DOI: 10.24252/ecc.v7i1.13197

\section{Abstrak : Dampak Angka Harapan Hidup dan Kesempatan Kerja Terhadap Kemiskinan}

Keberhasilan dari program pembangunan sosial ekonomi menjadi indikator indeks pembangunan manusia (IPM). Angka harapan hidup erat kaitannya dengan angka kematian bayi, Kesempatan Kerja, kemiskinan dan Pertumbuhan Ekonomi Provinsi Kalimantan Tengah. Penelitian ini bertujuan untuk menganalisis faktor-faktor Pengaruh Angka Harapan Hidup dan Kesempatan Kerja terhadap Kemiskinan Provinsi Kalimantan Tengah. Subjek penelitian ini adalah 14 Kabupaten/Kota di Provinsi Kalimantan Tengah, dengan tahun pengamatan 2011-2018. Data dalam penelitian ini adalah Angka Harapan Hidup, Kesempatan kerja, Kemiskinan, dan Kesempatan Kerja di Provinsi Kalimantan Tengah. Dengan menggunakan alat analisis Path Analysis (Analisis Jalur). Angka harapan hidup pada dasarnya merupakan gambaran kondisi suatu wilayah secara garis besar. Semakin tingginya angka harapan hidup di Provinsi Kalimantan Tengah menandakan adanya perbaikan status kesehatan masyarakat, termasuk peningkatan akses, kualitas pelayanan kesehatan yang mengurangi taraf kemiskinan karena meningkatnya peluang angkatan kerja di Provinsi Kalimantan Tengah. Hasil penelitian ini juga menunjukkan angkatan kerja dan pertumbuhan ekonomi harus memiliki strategi yang tepat untuk mensejahterakan masyarakat di Provinsi Kalimantan Tengah karena tidak terdampak positif dengan Program strategis yang selama ini berjalan dalam mengurangi kesenjangan pembangunan sosial masyarakat di Provinsi Kalimantan Tengah.

Kata kunci : Angka Harapan Hidup; Kesempatan Kerja; Kemiskinan; Pertumbuhan

Ekonomi. 


\section{Abstract: Effect of Life Expectancy and Employment Opportunities on Poverty}

The success of the socioeconomic development program is an indicator of the human development index (HDI). Life expectancy is closely related to infant mortality, employment opportunities, poverty and economic growth in Central Kalimantan Province. This study aims to analyze the factors of the influence of Life Expectancy and Employment Opportunities on Poverty in Central Kalimantan Province through Economic Growth. The subjects of this study were 14 districts / cities in Central Kalimantan Province, with an observation year 2011-2018. The data in this study are Life Expectancy, Job Opportunities, Poverty, and Job Opportunities in the Province of Central Kalimantan. By using the Path Analysis tool. Life expectancy is basically an outline of an area's condition. The higher life expectancy in Central Kalimantan Province indicates an improvement in the health status of the community, including increased access to, quality of health services, which reduces poverty levels due to increased labor force opportunities in Central Kalimantan Province. The results of this study also indicate that the workforce and economic growth must have the right strategy for the welfare of the people in Central Kalimantan Province because they are not positively affected by the strategic program that has been running in reducing the social development gap in Central Kalimantan Province.

Keywords : Economic Growth; Job Opportunities; Life Expectancy; Poverty.

\section{PENDAHULUAN / INTRODUCTION}

Bangsa Indonesia sejak merdeka sudah berupaya untuk mengurangi kemiskinan namun hasilnya jauh dari memuaskan. Hal ini disebabkan oleh berbagai faktor, yaitu tingkat investasi yang masih dibawah standar, tingkat pengangguran yang tinggi, dan pertumbuhan ekonomi yang lambat (Elyani. 2010). Kemiskinan dapat terjadi di daerah perkotaan maupun di daerah perdesaan ini menunjukkan suatu kondisi dimana seseorang tidak mampu untuk memenuhi kebutuhan dasarnya seperti pangan, sandang, tempat tinggal, pendidikan, dan kesehatan yang layak. Angka harapan hidup menjadi tolak ukur yang penting dalam kependudukan sebagai salah satu indikator dalam pengukuran kualitas penduduk. Tinggi rendahnya angka harapan hidup dapat menjadi pertimbangan dalam menggambarkan kemajuan sosial ekonomi masyarakat (Supriatna, 2006).

Nurmasyitah (2017) Pemerintah melakukan berbagai kebijakan lintas sektoral dalam mempercepat penurunan jumlah penduduk miskin. Kebijakan - kebijakan yang diambil diarahkan untuk menciptakan pertumbuhan ekonomi. Pertumbuhan ekonomi yang berkualitas dan terarah yang dimaksudkan adalah pertumbuhan yang merata dan dapat "menyentuh" 
penduduk miskin. Dalam rangka program pengentasan kemiskinan telah dirancang berbagai program pembinaan sumberdaya manusia dan sekaligus memperbaiki tingkat kesejahteraannya. Hal ini dimaksudkan untuk lebih memeratakan akses seluruh masyarakat terhadap proses pembangunan dan hasil-hasilnya. Selain itu perlu adanya perhatian khusus terhadap kelompok masyarakat miskin yang relatif tertinggal dan belum beruntung dibandingkan dengan kelompok lainnya.

Sharp dalam Mudrajad (1997) mencoba mengidentifikasi penyebab kemiskinan dipandang dari sisi ekonomi. Pertama, secara mikro, kemiskinan muncul karena adanya ketidaksamaan pola kepemilikan sumberdaya yang menimbulkan distribusi pendapatan yang timpang. Penduduk miskin hanya memiliki sumberdaya dalam jumlah terbatas dan kualitasnya rendah. Badan Pusat Statistik Provinsi Kalimantan Tengah mencatat jumlah penduduk miskin di Kalimantan Tengah per September 2018 sebanyak 136.446 orang, berkurang sekitar 5,10\% atau 1.438 orang dibandingkan September 2017 yang mencapai 137.884 orang.

Menurut pendapat Simanjuntak (1985) Tenaga kerja atau manpower terdiri dari angkata kerja dan bukan angkatan kerja. Angkatan kerja atau labor force adalah bagian tenaga kerja yang ingin dan yang benar-benar menghasilkan barang dan jasa. Angkatan kerja terdiri dari golongan yang bekerja dan golongan yang menganggur dan mencari pekerjaan. Kelompok bukan angkatan kerja terdiri dari golongan yang bersekolah, golongan yang mengurus rumah tangga, dan golongan lain - lain atau penerima pendapatan. Ketiga golongan dalam kelompok bukan angkatan kerja sewaktu - waktu dapat menawarkan jasanya untuk bekerja. Oleh sebab itu, kelompok ini sering dinamakan potensial labor force. Kondisi ketenagakerjaan di Provinsi Kalimantan Tengah dikeahui dari Indeks Pembangunan Ketenagakerjaan (IPK) Kalimantan Tengah pada 3 tahun terakhir (2016 - 2018) cukup mengalami peningkatan dari 59,40 di tahun 2016, meningkat ke 66,68 di tahun 2018. Dengan peningkatan IPK yang cukup signifikan ini, pembangunan ketenagakerjaan Kalimantan Tengah menempati urutan ke lima nasional namun belum optimal secara pemerataan di 14 kabupaten/kota di Provinsi Kalimantan Tengah.

Sedangkan Sukirno (2000) Menyebutkan Pertumbuhan ekonomi diartikan sebagai perkembangan kegiatan dalam perekonomian yang menyebabkan barang dan jasa yang diproduksi dalam masyarakat bertambah dan kemakmuran masyarakat meningkat. 
Pertumbuhan ekonomi dapat menjadi tolak ukur perkembangan suatu perekonomian di suatu negara atau daerah. Dari suatu periode ke periode lainnya kemampuan suatu daerah atau negara untuk menghasilkan barang dan jasa akan meningkat. Kemampuan peningkatan ini disebabkan oleh pertambahan faktor-faktor produksi baik dalam jumlah dan kualitasnya. Investasi akan menambah barang modal dan teknologi yang digunakan juga makin berkembang. Disamping itu tenaga kerja bertambah sebagai akibat perkembangan penduduk seiring dengan meningkatnya pendidikan dan keterampilan mereka. Namun demikian Pertumbuhan ekonomi di Provinsi Kalimantan Tengah triwulan IV 2017 sebesar 5,34 persen atau lebih rendah dibandingkan triwulan III 2017 yang tumbuh pada level 6,13 persen. Penurunan kinerja sektor pertambangan dan penggalian, serta sektor industri pengolahan menyebabkan melambatnya ekspor yang menjadi faktor penahan laju pertumbuhan ekonomi Kalteng pada akhir tahun 2017.

Keberhasilan dari berbagai program pembangunan sosial ekonomi menjadi indikator indeks pembangunan manusia (IPM). Angka harapan hidup erat kaitannya dengan angka kematian bayi, Kemiskinan, Kesejahteraan Masyarakat, Ketenagakerjaan dan Pertumbuhan Ekonomi. Badan pusat statistik (BPS) di Provinsi Kalimantan Tengah menyebutkan bahwa pada tahun 2016 angka harapan hidup masyarakat Kalimantan Tengah ada di kisaran angka 69,53 tahun ini disusul karena pertumbuhan ekonomi meningkat dan menurunya angka kemiskinan di wilayah Provinsi Kalimantan Tengah.

Berdasarkan latar belakang diatas, maka peneliti terdorong mengangkat permasalahan ini dalam bentuk penelitian tentang pengaruh angka harapan hidup $(\mathrm{AHH})$ dan kesempatan kerja terhadap kemiskinan di Provinsi Kalimantan Tengah melalui Pertumbuhan Ekonomi.

\section{TINJAUAN TEORITIK / LITERATURE REVIEW}

Menurut Jhingan (2012) Menyebutkan salah satu pengembangan sumber daya manusia yaitu fasilitas dan pelayanan kesehatan, pada umumnya diartikan mencakup semua pengeluaran yang mempengaruhi harapan hidup, kekuatan dan stamina, tenaga serta vitalitas rakyat, Rendahnya tingkat pelayanan kesehatan pada masyarakat akan berdampak pada masyarakat pekerja yang kurang produktif dengan tingkat mental terbelakang. hal ini akan berdampak terhadap produktifitas yang kurang tinggi dan mengakibatkan hasil output yang rendah. 
Kesehatan dan pendidikan merupakan indikator dalam Indeks Pembangunan Manusia (IPM). Todaro (2006) menyatakan bahwa hubungan antara pendapatan disatu sisi dan kesehatan serta pendidikan di sisi yang lain. Meskipun terkait erat, namun pendapatan rumah tangga yang tinggi tidak selalu menjamin tingginya tingkat kesehatan dan pendidikan. Tenaga kerja merupakan setiap orang yang mampu melakukan pekerjaan guna menghasilkan barang atau jasa baik untuk memenuhi kebutuhan sendiri maupun untuk masyarakat luas. Sumitro Djojohadikusumo (1985) Menyebutkan tenaga kerja merupakan semua orang yang bersedia dan sanggup, dan golongan ini meliputi mereka yang bekerja untuk diri sendiri, anggota keluarga yang tidak menerima bayaran serta mereka yang bekerja untuk menerima bayaran/upah/gaji.

Menurut Suparmoko (2002) angkatan kerja ialah penduduk yang belum bekerja namun siap untuk bekerja atau sedang mencari pekerjaan pada tingkat upah yang berlaku. Angkatan kerja terdiri atas golongan yang bekerja, dan golongan yang menggangur dan mencari pekerjaan. Sedangkan Simanjuntak (1985) Menyebutkan masalah pada bidang sub ketenagakerjaan yaitu mengatakan bahwa penawaran tenaga kerja yang tidak sesuai dengan kualifikasi yang diminta oleh pasar tenaga kerja, meskipun permintaan sangat tinggi. Teori makro ekonomi mengenai masalah pengganguran ini dijelaskan dalam pembangunan nasional yang merupakan faktor penentuan laju pertumbuhan perekonomian baik dalam kedudukannya sebagai tenaga kerja produktif. Ketidaksseimbangan ini membuat ketenagakerjaan tidak merata pada daerah atau suatu kota tertentu sehingga dapat menghambat laju pertumbuhan ekonomi pada suatu daerah tertentu.

Menurut Todaro dan Smith (2006) Pertumbuhan penduduk yang pesat pada suatu negara akan menyebabkan terjadinya kemiskinan kronis. Malthus melukiskan suatu kecenderungan universal bahwa jumlah populasi di suatu negara akan meningkat sangat cepat menurut deret ukur. Sementara itu, karena adanya proses pertambahan hasil yang semakin berkurang dari faktor produksi yang jumlahnya tetap, yaitu tanah, maka persediaan pangan hanya akan meningkat menurut deret hitung.

Menurut pendapat Samuelson dan Nordhaus (1997), Penduduk atau masyarakat miskin di negara berpenghasilan rendah adalah dikarenakan dengan dua faktor yaitu rendahnya tingkat kesehatan dan lambatnya kualitas mutu pendidikan. Dengan demikian, upaya pertama yang 
wajib dilakukan pemerintah ialah melakukan pemberantasan penyakit, perbaikan kesehatan dan gizi, perbaikan kualitas pendidikan dan meningkatkan keterampilan penduduknya atau masyarakat. upaya ini untuk memperbaiki kualitas sumber daya manusia (SDM) di suatu daerah.

Menurut Rahardjo Adisasmita (2011) berpendapat bahwa indikator yang dipergunakan untuk mengukur pertumbuhan ekonomi adalah tingkat pertumbuhan Produk Domestik Regional Bruto (PDRB). Alasan yang mendasari pemilihan PDRB sebagai sasaran indikator untuk mengukur pertumbuhan ekonomi adalah PDRB yang merupakan ialah jumlah nilai tambah yang dihasilkan oleh seluruh aktivitas produksi pada perekonomian daerah. Hal ini menunjukkan peningkatan PDRB yang mencerminkan peningkatan balas jasa kepada faktor produksi yang digunakan untuk aktivitas produksi tersebut.

Menurut Todaro (2006) menyebutkan bahwa pandangan ekonomi baru menganggap tujuan utama pembangunan ekonomi bukan hanya pertumbuhan PDB semata, tapi juga pengentasan kemiskinan, penanggulangan ketimpangan pendapatan dan penyediaan lapangan kerja dalam konteks perekonomian yang terus berkembang. Hal tersebut dapat dimaknai bahwa kemiskinan menjadi salah satu masalah yang harus diatasi.

Sedangkan Arsyad (1999) Menyebutkan pertumbuhan ekonomi diartikan sebagai kenaikan Produk Domestik Bruto/ Pendapatan Nasional Bruto tanpa memandang apakah kenaikan tersebut lebih besar atau lebih kecil dari tingkat pertumbuhan penduduk atau apakah perubahan struktur ekonomi terjadi atau tidak.

\section{METODE PENELITIAN / METHODS}

Menurut Sugiyono, (2015) Populasi merupakan wilayah generalisasi yang terdiri atas objek/subjek yang mempunyai kualitas dan karakteristik tertentu yang diterapkan oleh peneliti untuk mempelajari dan kemudian ditarik kesimpulannya. Populasi pada penelitian ini adalah kabupaten/kota di Provinsi Kalimantan Tengah diantaranya 13 kabupaten dan 1 kota, dengan periode observasi selama delapan tahun terakhir dari periode 2011 - 2018. Berdasarkan data dari gabungan data time 8 tahun dan cross section 13 kabupaten dan 1 kota Provinsi Kalimantan Tengah akan diperoleh 112 sebagai jumlah objek penelitian.

Teknik dalam mengumpulkan data penelitian ini menggunakan pendekatan Library Research Approach (Pendekatan Riset Kepustakaan) dimana data yang akan diperoleh melalui 
pencatatan langsung dari pihak atau lembaga yang sudah menyediakan data terkait pada penelitian ini. Data yang digunakan merupakan data publikasi resi dari instansi pemerintahan daerah setempat dan Badan Pusat Statistik (BPS) Provinsi Kalimantan Tengah. Teknik Analisis Statistik yang digunakan untuk mengolah data ini dengan software statistical Package for the social sciences (SPSS) dengan analisis Path Analysis (Analisis Jalur) model persamaan struktural pada penelitian ini sebagai berikut:

1. Model Persamaan 1: Z = b1 Z X1 + b2 Z X2 + E

2. Model Persamaan 2: $\mathrm{Y}=\mathrm{b} 1 \mathrm{YX} 1+\mathrm{b} 2 \mathrm{YZ}+\mathrm{b} 3 \mathrm{YX} 2+\mathrm{E}$

$$
\begin{array}{ll}
\text { Keterangan : } & \\
\text { b1, b2, b3 = Koefisien Jalur } & \mathrm{Z}=\text { PDRB } \\
\mathrm{X} 1=\text { Angka Harapan Hidup } & \mathrm{Y}=\text { Kemiskinan } \\
\mathrm{X} 2=\text { Angkatan Kerja } & \mathrm{E}=\text { Error }
\end{array}
$$

\section{HASIL DAN PEMBAHASAN / RESULT AND DISCUSSION}

Angka Harapan Hidup $(\mathrm{AHH})$ adalah perkiraan rata-rata tambahan umur seseorang yang diharapkan dapat terus hidup. AHH juga dapat didefenisikan rata-rata jumlah tahun yang dijalani oleh seseorang setelah orang tersebut mencapai ulang tahun yang ke-x. Ukuran yang umum digunakan adalah angka harapan hidup saat lahir yang mencerminkan kondisi kesehatan pada saat itu. Angka Harapan Hidup untuk 13 Kabupaten dan 1 Kota di Provinsi Kalimantan Tengah.

Angka Harapan Hidup pada 13 Kabupaten dan 1 Kota di Provinsi Kalimantan Tengah periode Tahun 2011-2018 secara umum mengalami peningkatan secara konstan. Berdasarkan grafik di bawah terlihat bahwa Angka Harapan Hidup pada Kabupaten/Kota di Provinsi Kalimantan Tengah sepanjang periode penelitian tahun 2011-2018 terus mengalami peningkatan. Untuk mengetahui lebih jelas tentang perkembangan Angka Harapan Hidup pada Kabupaten/Kota di Provinsi Kalimantan Tengah pada periode 2011-2018 dapat dilihat pada gambar grafik sebagai berikut. 
Gambar 1.

Grafik Angka Harapan Hidup pada Kabupaten/Kota

Provinsi Kalimantan Tengah Periode 2011-2018

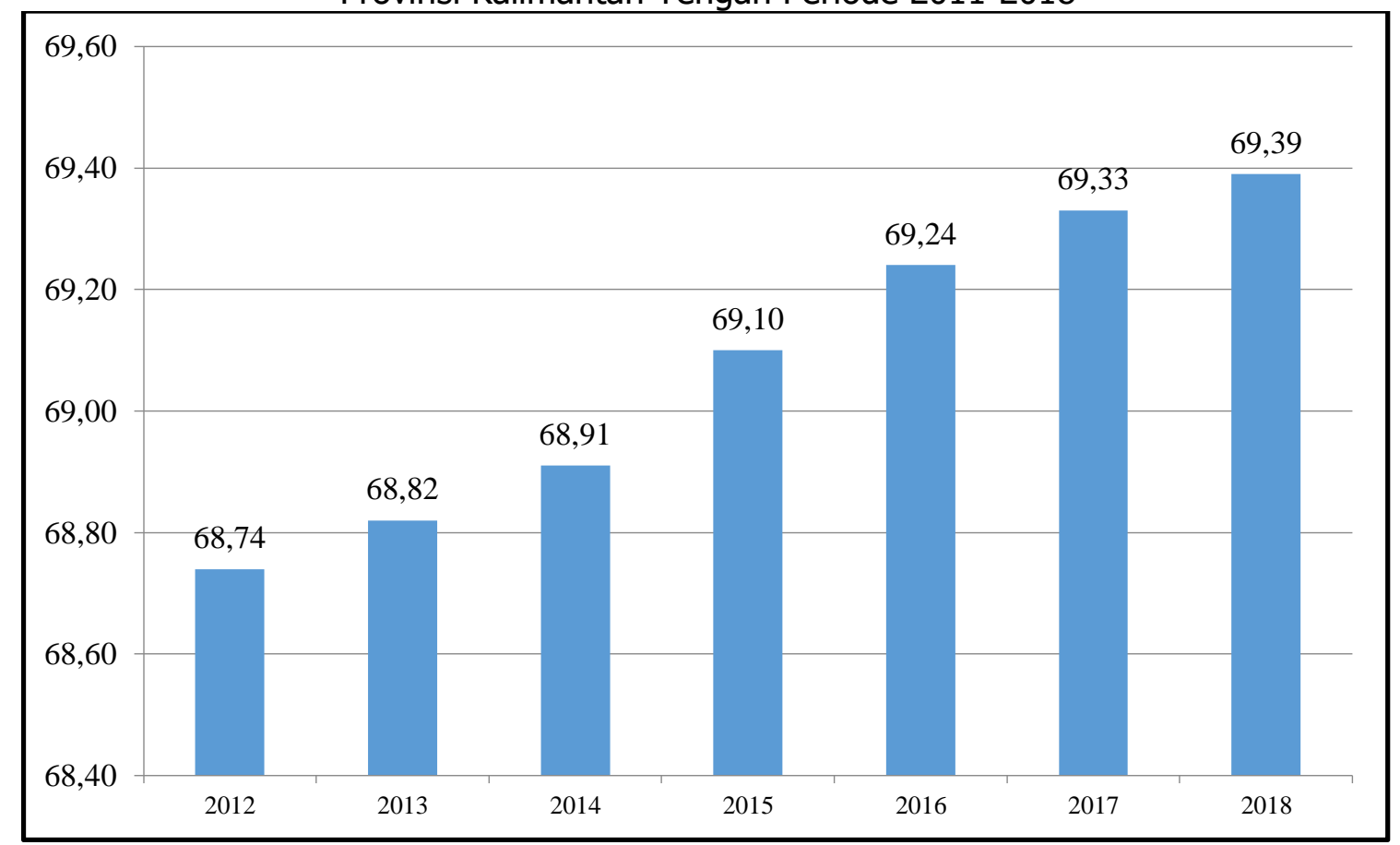

Sumber: BPS Kalimatan Tengah, 2019.

$\mathrm{AHH}$ adalah rata-rata jumlah tahun yang akan dijalani oleh seseorang sejak orang tersebut lahir. Berdasarkan data angka harapan hidup untuk Kabupaten/Kota di Kalimantan Tengah diketahui bahwa Angka Harapan Hidup terendah terjadi pada tahun 2011 yaitu 68,74 kemudian terus mengalami peningkatan hingga tahun 2018 yaitu di angka 69,39. Hasil perhitungan secara keseluruhan menunjukkan bahwa rata-rata Angka Harapan Hidup untuk Provinsi Kalimantan Tengah terus mengalami peningkatan, hal ini menunjukkan bahwa Pemerintah Provinsi Kalimantan Tengah terus berupaya meningkatan kesejahteraan masyarakat untuk meningkatkan Angkatan kerja Provinsi Kalimantan Tengah.

Angkatan Kerja merupakan jumlah penduduk usia kerja (usia 15 tahun ke atas) yang bekerja melakukan kegiatan ekonomi yang menghasilkan barang atau jasa secara berkelanjutan paling sedikit satu jam dalam seminggu (BPS, 2015) di Provinsi Kalimantan Tengah, dinyatakan dalam satuan orang.

Angkatan kerja merupakan jumlah penduduk yang dapat melakukan kegiatan ekonomi yang menghasilkan barang/jasa secara berkelanjutan paling sedikit satu jam dalam seminggu. Berdasarkan grafik di bawah terlihat bahwa angkatan kerja pada Kabupaten/Kota di Provinsi 
Kalimantan Tengah sepanjang periode penelitian tahun 2011-2018 fluktuatif mengalami peningkatan atau penurunan secara konstan. Untuk mengetahui lebih jelas tentang perkembangan angkatan kerja pada Kabupaten/Kota di Provinsi Kalimantan Tengah pada periode 2011-2018 dapat dilihat pada gambar grafik sebagai berikut.

Berdasarkan data angkatan kerja untuk Kabupaten/Kota di Kalimantan Tengah diketahui bahwa angkatan kerja terendah pada tahun 2013 yaitu 78401,93, tertinggi angkatan kerja pada tahun 2018 yaitu 96814,21. hal ini menunjukkan bahwa jumlah penduduk yang melakukan kegiatan ekonomi yang menghasilkan barang/jasa secara berkelanjutan paling sedikit satu jam dalam seminggu di Provinsi Kalimantan Tengah bervariatif terlihat pada grafik yang ada.

Gambar 2.

Grafik Rata-Rata Angkatan Kerja pada Kabupaten/Kota Provinsi Kalimantan Tengah Periode 2011-2018

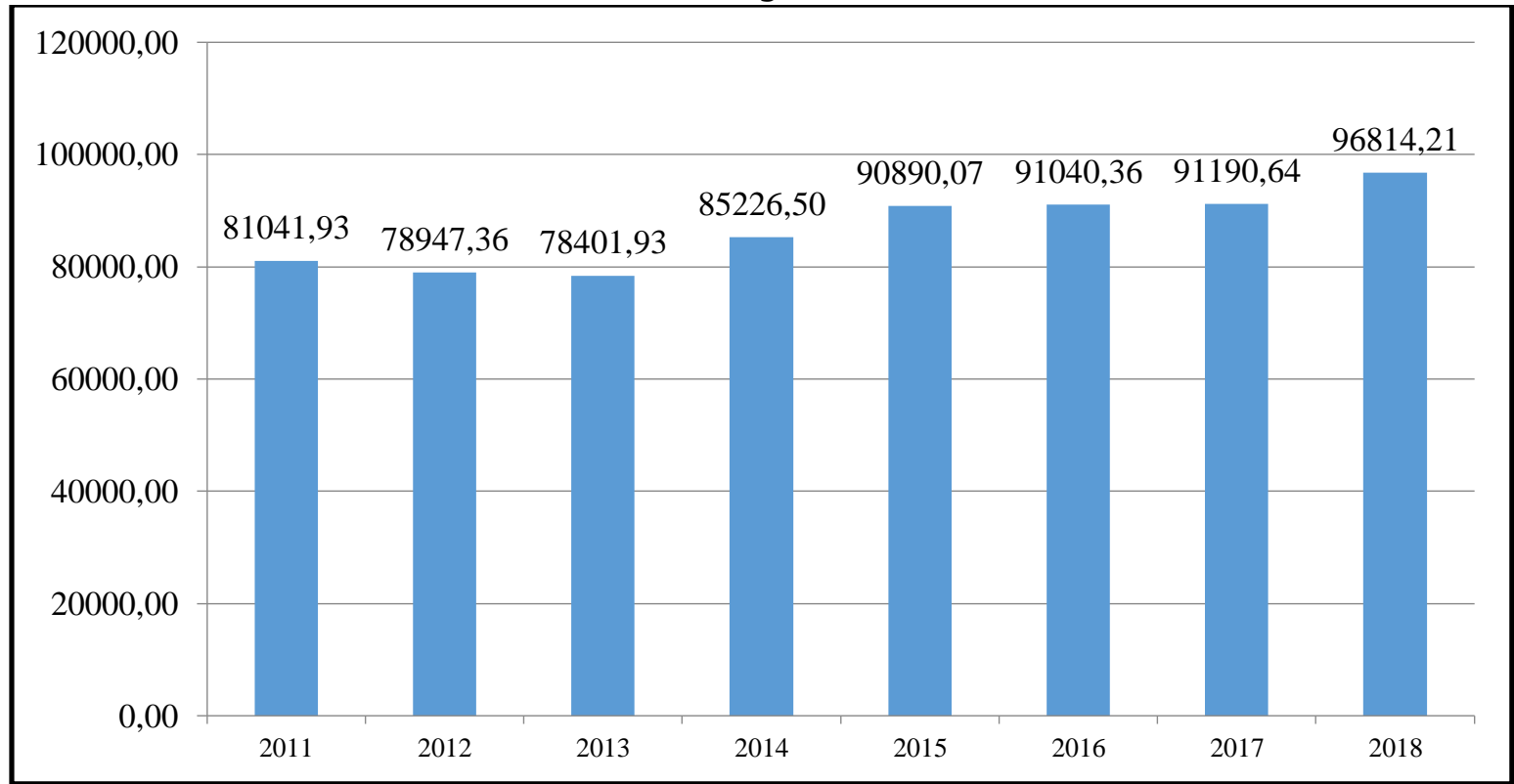

Sumber: BPS Kalimatan Tengah, 2019.

PDRB adalah keseluruhan nilai tambah barang dan jasa oleh berbagai sektor ekonomi di suatu daerah dalam waktu tertentu. PDRB atas dasar harga konstan digunakan untuk menunjukkan laju pertumbuhan ekonomi secara keseluruhan dari tahun ke tahun. PDRB harga konstan menunjukkan nilai tambah barang dan jasa yang dihitung menggunakan harga tahun 2011 sebagai tahun dasar. Berdasarkan tabel 3 diatas dapat terlihat bahwa PDRB pada Kabupaten/Kota di Provinsi Kalimantan Tengah sepanjang periode penelitian tahun 201150 
2018 terus meningkat. Untuk mengetahui lebih jelas tentang perkembangan PDRB harga konstan pada Kabupaten/Kota di Provinsi Kalimantan Tengah pada periode 2011-2018 dapat dilihat pada gambar grafik sebagai berikut.

Gambar 3.

Grafik Rata-Rata PDRB pada Kabupaten/Kota

di Provinsi Kalimantan Tengah Periode 2011-2018

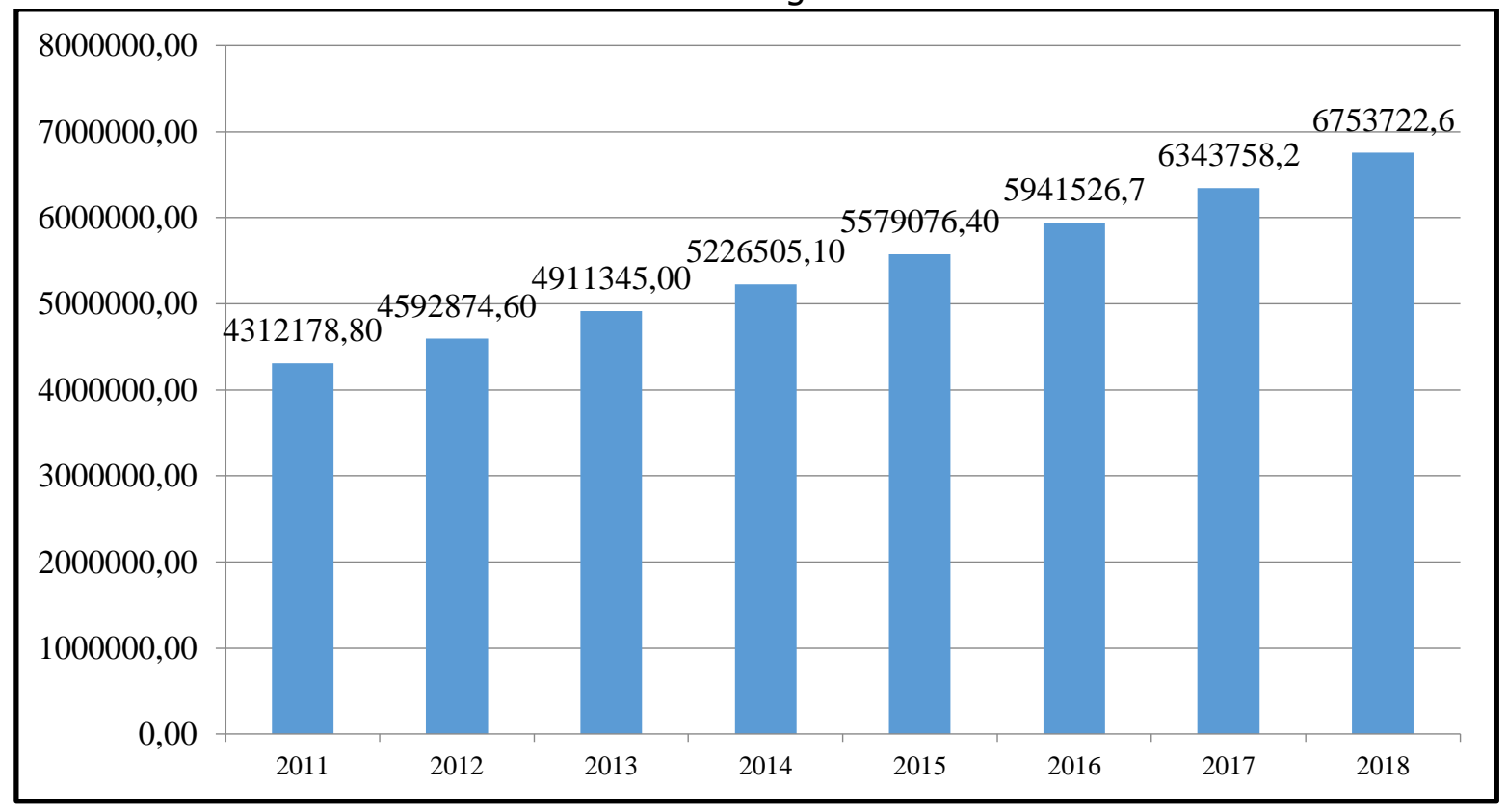

Sumber: BPS Kalimatan Tengah, 2019.

Produk Domestik Regional Bruto merupakan jumlah nilai tambah yang dihasilkan oleh seluruh aktivitas produksi di dalam perekonomian. Berdasarkan data PDRB untuk Kabupaten dan Kota di Kalimantan Tengah diketahui bahwa PDRB terendah terjadi pada tahun 2011 yaitu sebesar 4312178,8 kemudian terus mengalami peningkatan hingga tahun 2018 sebesar 10150883,0 Hasil perhitungan secara keseluruhan menunjukkan bahwa rata-rata peningkatan PDRB untuk Provinsi Kalimantan Tengah mengalami peningkatan sebesar, hal ini menunjukkan bahwa pemerintah Provinsi Kalimantan Tengah terus berupaya meningkatan nilai tambah yang dihasilkan oleh seluruh aktivitas produksi di dalam perekonomian untuk menurunkan angka kemiskinan.

Kemiskinan sesungguhnya merupakan masalah klasik yang masih terus dihadapi oleh bangsa manapun sampai saat ini. Bahkan, negara maju sekalipun belum mampu sepenuhnya menuntaskan kemiskinan, apalagi negara sedang berkembang seperti Indonesia. Terlihat bahwa tingkat kemiskinan pada Kabupaten/Kota di Provinsi Kalimantan Tengah sepanjang periode 
penelitian tahun 2011-2018 terus mengalami penurunan. Untuk mengetahui lebih jelas tentang perkembangan tingkat kemiskinan pada Kabupaten/Kota di Provinsi Kalimantan Tengah pada periode 2011-2018 dapat dilihat pada gambar grafik sebagai berikut.

\section{Gambar 4.}

Grafik Rata-Rata Tingkat Kemiskinan pada Kabupaten/Kota

di Provinsi Kalimantan Tengah Periode 2011-2018

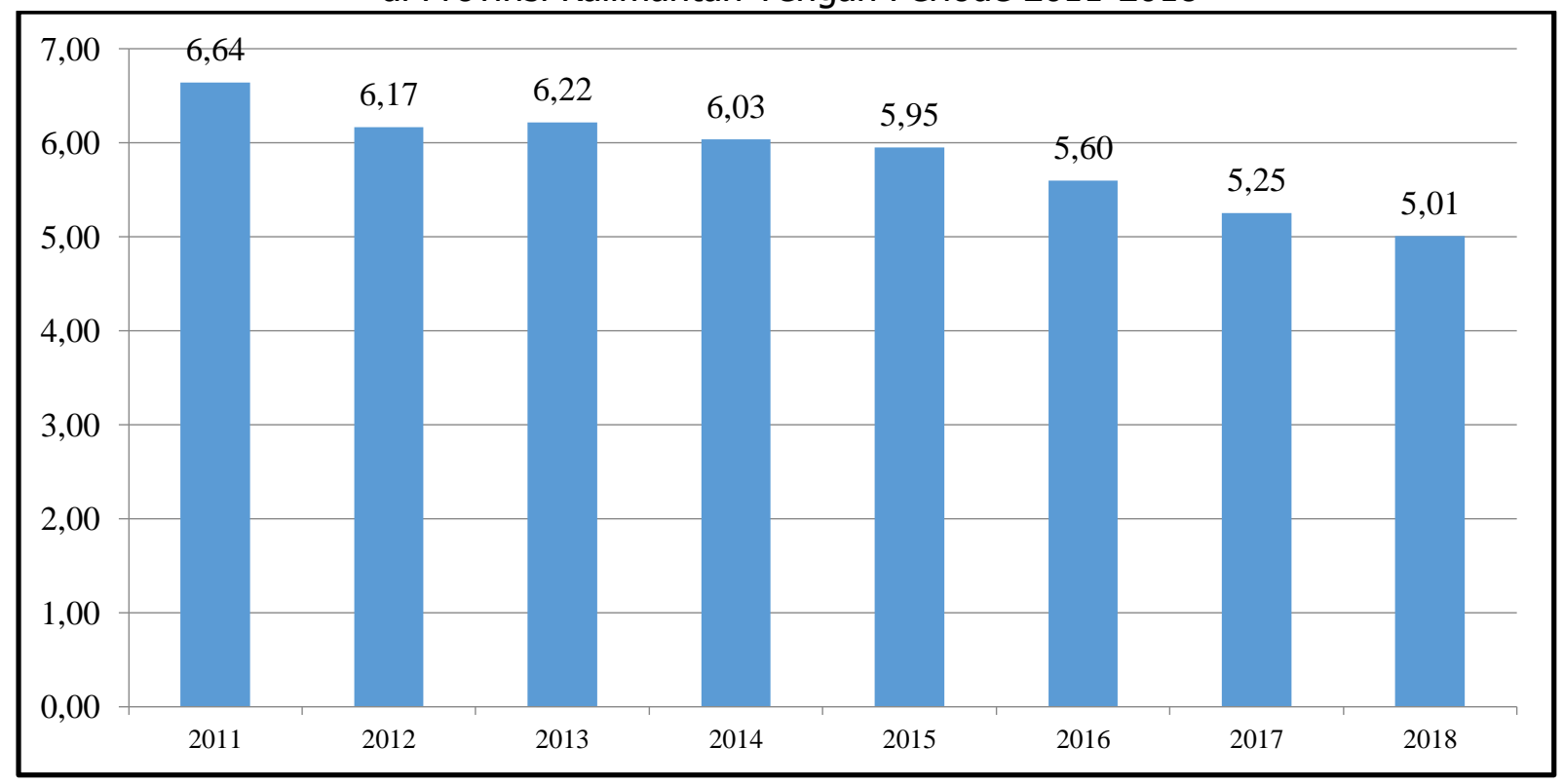

Sumber: BPS Kalimatan Tengah, 2019.

Kemiskinan merupakan kondisi di mana seseorang atau sekelompok orang tidak mampu memenuhi hak-hak dasarnya untuk mempertahankan dan mengembangkan kehidupan yang bermartabat, di mana kemiskinan dipandang sebagai ketidak mampuan dari sisi ekonomi untuk memenuhi kebutuhan dasar makanan dan bukan makanan (diukur dari sisi pengeluaran). Berdasarkan data tingkat kemiskinan untuk Kabupaten dan Kota di Kalimantan Tengah diketahui bahwa tingkat kemiskinan tertinggi terjadi pada tahun 2011 yaitu sebesar $6.64 \%$ kemudian terus mengalami penurunan hingga tahun 2018 sebesar 5,01\%. Hasil perhitungan secara keseluruhan menunjukkan bahwa rata-rata tingkat kemiskinan untuk Provinsi Kalimantan Tengah mengalami penurunan, hal ini menunjukkan bahwa pemerintah Provinsi Kalimantan Tengah terus berupaya meningkatkan upaya menurunkan persentase penduduk yang tidak dapat memenuhi kebutuhannya. 
Berikut disajikan hasil analisis path antara Angka Harapan Hidup (X1), Angkatan Kerja (X2), PDRB (Z), dan Kemiskinan (Y).

1. Struktur 1: Pengaruh Angka Harapan Hidup (X1) dan Angkatan Kerja (X2) terhadap PDRB (Z)

Berikut disajikan hasil path struktur 1 yaitu pengaruh antara Angka Harapan Hidup (X1) dan Angkatan Kerja (X2) terhadap PDRB (Z).

Tabel 1.

Hasil Uji Path Struktur 1

\begin{tabular}{|c|c|c|c|c|c|c|}
\hline \multirow[t]{2}{*}{ Model } & \multicolumn{3}{|c|}{$\begin{array}{l}\text { Unstandardized } \\
\text { Coefficients }\end{array}$} & $\begin{array}{l}\text { Standardized } \\
\text { Coefficients }\end{array}$ & \multirow[t]{2}{*}{$t$} & \multirow[t]{2}{*}{ Sig. } \\
\hline & B & Std. & Error & Beta & & \\
\hline 1 (Constant) & & 22879433,158 & $\begin{array}{r}4038337 \\
, 772\end{array}$ & & $-5,666$ & ,000 \\
\hline $\mathrm{AHH}$ & & 336098,215 & $\begin{array}{r}58737,5 \\
43\end{array}$ & 198 & 5,722 & ,000 \\
\hline $\begin{array}{l}\text { Angkatan } \\
\text { erja }\end{array}$ & & 59,271 & 2,305 & 890 & 25,717 & ,000 \\
\hline
\end{tabular}

Sumber : Data primer diolah, tahun 2019.

Hasil uji path struktur 1 pada pengaruh antara Angka Harapan Hidup (X1) dan Angkatan Kerja (X2) terhadap PDRB (Z) diperoleh persamaan sebagai berikut:

$$
\begin{aligned}
& Z=P_{Z X 1} X 1+P_{Z X 2} X 2+e_{1} \\
& Z=0,198 X 1+0,890 X 2+e_{1}
\end{aligned}
$$

Dari persamaan tersebut diketahui bahwa terdapat pengaruh positif antara Angka Harapan Hidup (X1) dan Angkatan Kerja (X2) terhadap PDRB (Z).

\section{Struktur 2: Pengaruh Angka Harapan Hidup (X1), Angkatan Kerja (X2), dan PDRB (Z) terhadap Kemiskinan (Y)}

Berikut ini disajikan hasil path struktur 2 yaitu pengaruh antara Angka Harapan Hidup (X1), Angkatan Kerja (X2), dan PDRB (Z) terhadap Kemiskinan (Y). 
Hasil uji path struktur 2 pada pengaruh antara Angka Harapan Hidup (X1), Angkatan Kerja (X2), dan PDRB (Z) terhadap Kemiskinan (Y) diperoleh persamaan sebagai berikut:

$$
\begin{aligned}
& Y=P_{Y X 1} X 1+P_{Y X 2} X 2+P_{Y Z} Z+e_{2} \\
& Y=-0,459 X 1+0,092 X 2+0,014 Z+e_{2}
\end{aligned}
$$

Dari persamaan tersebut diketahui bahwa terdapat pengaruh positif antara Angka Harapan Hidup (X1), Angkatan Kerja (X2), dan PDRB (Z) terhadap Kemiskinan (Y).

Tabel 2.

Hasil Uji Path Struktur 2

\begin{tabular}{llcccc} 
Model & \multicolumn{2}{c}{$\begin{array}{c}\text { Unstandardizd } \\
\text { Coefficients } \\
\text { B }\end{array}$} & $\begin{array}{c}\text { Standardized } \\
\text { Coefficients } \\
\text { Beta }\end{array}$ & t & Sig. \\
\hline (Constant) & 27.788 & 4.725 & & 5.881 & .000 \\
Angka Harapan & -.321 & .069 & -.459 & 4.666 & .000 \\
Hidup & & & & & \\
& & & & .402 & .688 \\
Angkatan Kerja & $2.534 \mathrm{E}-006$ & .000 & .092 & .059 & .953 \\
PDRB & $5.823 \mathrm{E}-009$ & .000 & .014 & & \\
\hline
\end{tabular}

Sumber : Data primer diolah, tahun 2019.

Pengujian Hipotesis: Berikut disajikan hasil pengujian hipotesis dengan menggunakan analisis path antara Angka Harapan Hidup (X1), Angkatan Kerja (X2), PDRB (Z), dan Kemiskinan (Y).

Tabel 3. Hasil Uji Hipotesis

\begin{tabular}{clllll}
\hline No. & Pengaruh & $\begin{array}{l}\text { Koef. } \\
\text { Jalur }\end{array}$ & T Statistik & Sig. & Ket. \\
\hline $\mathbf{1}$ & $\mathrm{X} 1 \rightarrow \mathrm{Z}$ & 0.198 & 5.722 & 0.000 & Signifikan \\
$\mathbf{2}$ & $\mathrm{X} 2 \rightarrow \mathrm{Z}$ & 0.890 & 25.717 & 0.000 & Signifikan \\
$\mathbf{3}$ & $\mathrm{X} 1 \rightarrow \mathrm{Y}$ & 0.459 & 4.666 & 0.000 & Signifikan \\
$\mathbf{4}$ & $\mathrm{X} 2 \rightarrow \mathrm{Y}$ & 0.092 & 0.402 & 0.688 & Tidak signifikan \\
$\mathbf{5}$ & $\mathrm{Z} \rightarrow \mathrm{Y}$ & 0.014 & 0.059 & 0.953 & Tidak signifikan \\
$\mathbf{6}$ & $\mathrm{X} 1 \rightarrow \mathrm{Z} \rightarrow \mathrm{Y}$ & 0.003 & 5.722 & 0.000 & Signifikan \\
$\mathbf{7}$ & $\mathrm{X} 2 \rightarrow \mathrm{Z} \rightarrow \mathrm{Y}$ & 0.012 & 25.714 & 0.000 & Signifikan \\
\end{tabular}

Sumber : Data primer diolah, tahun 2019.

Hasil pengujian hipotesis dijabarkan sebagai berikut: 


\section{Implikasi Angka Harapan Hidup (X1) terhadap PDRB (Z) di Provinsi Kalimantan Tengah.}

Hasil penelitian menunjukkan Pengaruh Angka Harapan Hidup (X1) terhadap PDRB (Z) sehingga terdapat pengaruh positif signifikan, artinya semakin tinggi Angka Harapan Hidup (X1) akan berpengaruh terhadap semakin tinggi PDRB (Z) diperoleh koefisien jalur sebesar 0,198 dengan nilai signifikansi sebesar 0,000 $(p<0,05) \mathrm{Hal}$ ini ditunjukkan dari hasil koefisien angka harapan hidup sebesar 0,198 artinya setiap kenaikan angka harapan hidup sebesar 1 satuan maka akan menaikkan PDRB di Provinsi Kalimantan Tengah sebesar19.8\%.

Penelitian ini sejalan dengan penelitian yang dilakukan Edi Dores (2014) Secara bersamaan bahwa pendidikan yang diukur dengan angka melek huruf dan kesehatan yang diukur dengan angka harapan hidup $(\mathrm{AHH})$ berpengaruh secara signifikan terhadap jumlah penduduk miskin di wilayah provinsi Sumatera Barat.

Penelitian ini juga sejalan dengan Penelitian Riyan Muda, Dkk (2019) bahwa dinyatakan variabel kesehatan $(\mathrm{AHH})$ berpengaruh singnifikan terhadap pertumbuhan ekonomi (PDRB) yang disebabkan oleh kesehatan berdampak kepada seluruh masyarakat (tenaga kerja). Semakin banyaknya masyarakat yang berdampak suatu penyakit maka akan menghancurkan vitalitas, produktivitas, efisiensi dan bahkan melemahkan inisiatif dan aktivitas sosial tenaga kerja di daerah tersebut.

\section{Implikasi Pengaruh Angkatan Kerja (X2) terhadap PDRB (Z) di Provinsi Kalimantan Tengah.}

Hasil penelitian menunjukkan Pengaruh Angkatan Kerja (X2) terhadap PDRB (Z) terdapat pengaruh positif signifikan, artinya semakin tinggi Angkatan Kerja (X2) akan berpengaruh terhadap semakin tinggi PDRB (Z). dapat diperoleh koefisien jalur sebesar 0,890 dengan nilai signifikansi sebesar 0,000 $(p<0,05)$ Sehingga hal ini ditunjukkan dari hasil koefisien angka Angkatan Kerja di Provinsi Kalimantan Tengah sebesar 0,890 artinya setiap kenaikan angka harapan hidup sebesar 1 satuan maka akan menaikkan PDRB di Provinsi Kalimantan Tengah sebesar $89.0 \%$.

Penelitian ini sejalan dengan penelitian yang dilakukan Batari Sraswati (2013), menyebutkan bahwa Tenaga Kerja berpengaruh Positif dan tidak signifikan terhadap PDRB. 


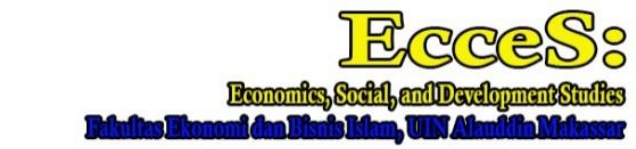

Volume 7 Nomor 1 Ed. Juni 2020: page 42-61

p-ISSN: 2407-6635 e-ISSN : 2580-5570

Karena semakin banyak Tenaga Kerja maka berakibat pada kenaikan pendapatan perkapita, penurunan pendapatan perkapita berakibat pada penurunan pertumbuhan ekonomi, jika pertumbuhan ekonomi naik maka semakin besar pula para pekerja mendapatkan pekerjaan.

\section{Implikasi Angka Harapan Hidup (X1) terhadap Kemiskinan (Y) di Provinsi Kalimantan Tengah.}

Hasil penelitian menunjukkan Pengaruh Angka Harapan Hidup (X1) terhadap Kemiskinan (Y) terdapat pengaruh negatif signifikan, artinya semakin tinggi Angka Harapan Hidup (X1) akan berpengaruh terhadap semakin rendah Kemiskinan (Y). diperoleh koefisien jalur sebesar -0,459 dengan nilai signifikansi sebesar 0,000 ( $p<0,05)$ sehingga hal ini ditunjukkan dari hasil koefisien angka harapan hidup terhadap kemiskinan di Provinsi Kalimantan Tengah sebesar 0,459 artinya setiap kenaikan angka harapan hidup sebesar 1 satuan maka akan menurunkan tingkat kemiskinan di Provinsi Kalimantan Tengah sebesar 45.9\%.

Penelitian ini didukung juga dengan Penelitian oleh Rahmawati Faturrohmin (2011), menyatakan bahwa Angka Harapan Hidup berpengaruh signifikan terhadap tingkat kemiskinan di 35 Kabupaten/Kota di wilayah Jawa Tengah.

\section{Implikasi Angkatan Kerja (X2) terhadap Kemiskinan (Y) di Provinsi Kalimantan Tengah.}

Hasil penelitian menunjukkan Pengaruh Angkatan Kerja (X2) terhadap Kemiskinan (Y) di Provinsi Kalimantan Tengah terdapat pengaruh positif namun tidak signifikan, artinya semakin tinggi Angkatan Kerja (X2) tidak akan berpengaruh terhadap semakin tinggi Kemiskinan (Y). dimana terlihat pada koefisien jalur sebesar 0,092 dengan nilai signifikansi sebesar 0,688 ( $p$ > 0,05) sehingga Angkatan Kerja berpengaruh terhadap Kemiskinan di Provinsi Kalimantan Tengah. hal ini ditunjukkan dari hasil koefisien angkatan kerja terhadap kemiskinan di Provinsi Kalimantan Tengah sebesar 0,092 artinya setiap kenaikan angkatan kerja sebesar 1 satuan maka akan menurunkan kemiskinan di Provinsi Kalimantan Tengah sebesar 9.2\%. 
Penelitian ini didukung juga dengan Penelitian Gusti Ayu (2017), Pengaruh tenaga maka disimpulkan Tenaga kerja berpengaruh negatif dan signifikan terhadap tingkat kemiskinan pada Wilayah Sarbagita di Provinsi Bali.

\section{Implikasi PDRB (Z) terhadap Kemiskinan (Y)}

Hasil penelitian menunjukkan Pengaruh PDRB (Z) terhadap Kemiskinan (Y) diperoleh koefisien jalur sebesar $-0,014$ dengan nilai signifikansi sebesar 0,953 ( $p>0,05)$ sehingga terdapat pengaruh positif namun tidak signifikan, artinya semakin tinggi PDRB ( $Z$ ) tidak akan berpengaruh terhadap semakin tinggi Kemiskinan $(Y)$. hal ini ditunjukkan dari hasil koefisien PDRB terhadap kemiskinan di Provinsi Kalimantan Tengah sebesar 0,092 artinya setiap kenaikan PDRB sebesar 1 satuan maka akan menurunkan kemiskinan di Provinsi Kalimantan Tengah sebesar 9.2\%. Penelitian ini didukung juga dengan Penelitian Rahmawati (2011), Menyatakan bahwa PDRB berpengaruh signifikan terhadap tingkat kemiskinan di 35 Kabupaten di Jawa Tengah.

\section{Implikasi secara tidak langsung Angka Harapan Hidup (X1) melalui PDRB (Z) terhadap Kemiskinan (Y) di Provinsi Kalimantan Tengah.}

Pengaruh secara tidak langsung Angka Harapan Hidup (X1) melalui PDRB (Z) terhadap Kemiskinan $(Y)$ diperoleh koefisien jalur sebesar 0,003 dengan nilai signifikansi sebesar 0,000 ( $p$ $<0,05)$ sehingga terdapat pengaruh positif signifikan, artinya secara tidak langsung semakin tinggi Angka Harapan Hidup (X1) akan berpengaruh terhadap semakin tinggi Kemiskinan (Y) melalui PDRB $(Z)$ yang tinggi.

Penelitian ini didukung juga dengan Penelitian Rahmawati (2011), Menyatakan bahwa variabel PDRB, Harapan Hidup dan Melek Huruf berpengaruh terhadap Penurunan kemiskinan di 35 kabupaten/kota di jawa tengah pada periode 2005-2009. Hal ini dapat terlihat pada nilai Fhitung yang signifikan pada tingkat kepercayaan 95 persen. Dalam Penelitian Anggraini (2013), Menyebutkan bahwa pada peningkatan indikator lingkungan seperti kualitas fisik air minum yang berkualitas, rumah tangga yang memiliki akses pembuangan tinja yang layak dengan kriteria rumah sehat dapat mempengaruhi peningkatan angka harapan hidup (AHH) juga digunakan sebagai indikator untuk menilai derajat kesehatan penduduk serta kemiskinan. 
Semakin tinggi nilai angka harapan hidup di suatu wilayah, maka mengindikasikan pembangunan sosial ekonomi terutama yang terkait dengan fasilitas kesehatan wilayah tersebut semakin maju serta mengurangi angka kemiskinan yang akan mempengaruhi pertumbuhan ekonomi masyarakat semakin meningkat.

\section{Implikasi Angkatan Kerja (X2) melalui PDRB (Z) terhadap Kemiskinan (Y) di Provinsi Kalimantan Tengah.}

Hasil penelitian menunjukkan Pengaruh secara tidak langsung Angkatan Kerja (X2) melalui PDRB (Z) terhadap Kemiskinan (Y) diperoleh koefisien jalur sebesar 0,012 dengan nilai signifikansi sebesar 0,000 ( $p<0,05)$ sehingga terdapat pengaruh positif signifikan, artinya secara tidak langsung semakin tinggi Angkatan Kerja (X2) akan berpengaruh terhadap semakin tinggi Kemiskinan $(\mathrm{Y})$ melalui PDRB (Z) yang tinggi.

Penelitian ini sejalan dengan penelitian yang dilakukan M. Iqraam, dkk (2019), Menunjukkan Secara simultan variabel PDRB, pendidikan, kesempatan kerja dan persentase penduduk di sektor informal berpengaruh signifikan terhadap kemiskinan di Provinsi Bali dan PDRB secara parsial berpengaruh positif dan tidak signifikan terhadap kemiskinan di Provinsi Bali tahun 2001-2017

\section{KESIMPULAN / CONCLUSION}

Angka harapan hidup pada dasarnya merupakan gambaran kondisi suatu wilayah secara garis besar. Semakin tingginya angka harapan hidup di Provinsi Kalimantan Tengah menandakan adanya perbaikan status kesehatan masyarakat, termasuk peningkatan akses, kualitas pelayanan kesehatan yang mengurangi taraf kemiskinan karena meningkatnya peluang angkatan kerja di Provinsi Kalimantan Tengah. Hasil penelitian ini juga menunjukkan angkatan kerja dan pertumbuhan ekonomi harus memiliki strategi yang tepat untuk mensejahterakan masyarakat di Provinsi Kalimantan Tengah karena tidak terdampak positif dengan Program strategis yang selama ini berjalan dalam mengurangi kesenjangan pembangunan sosial masyarakat di Provinsi Kalimantan Tengah. 


\section{DAFTAR PUSTAKA / REFERENCES}

Adisasmita, R. 2011. Manajemen Pemerintah Daerah. Yogyakarta: Graha Ilmu

Anggraini E. 2013. Disparitas Spasial Angka Harapan Hidup di Indonesia Tahun 2010. Jurnal Bumi Indonesia, 2(3), pp. 71-80.

Arsyad, L. 1999. Ekonomi Pembangunan. Edisi Keempat. Yogyakarta: STIE YKPN

Badan Pusat Statistik Provinsi Kalimantan Tengah. 2016. Statistik Kesejahteraan Rakyat Provinsi Kalimantan Tengah 2018. Palangka Raya: Badan Pusat Statistik.

Badan Pusat Statistik Provinsi Kalimantan Tengah. 2016. Provinsi Kalteng Dalam Angka 2018. Palangka Raya: Badan Pusat Statistik.

Badan Pusat Statistik Provinsi Kalimantan Tengah. 2016. Provinsi Kalteng Dalam Angka 2017. Palangka Raya: Badan Pusat Statistik.

Badan Pusat Statistik Provinsi Kalimantan Tengah. 2016. Laporan Perekonomian Provinsi Kalimantan Tengah 2018. Palangka Raya: Badan Pusat Statistik.

Badan Pusat Statistik Provinsi Kalimantan Tengah. 2016. Indikator Kesejahteraan Rakyat Provinsi Kalimantan Tengah 2016. Palangka Raya: Badan Pusat Statistik.

Dores, Sraswati, B. 2013. Pengaruh Investasi, Tenaga Kerja dan Ekspor Terhadap PDRB Sektor Indusri Di Kota Semarang. Vol. 2, No. 4 ISNN: 2337-3814.

Edi. 2014. Pengaruh Angka Melek Huruf dan Angka Harapan Hidup terhadap Jumlah Penduduk Miskin di Provinsi Sumatera Barat. Jurnal: Economika, Volume 2 Nomor 2 Ed. 2014: page 126-133

Djojohadikusumo, Sumitro. 1985. Ekonomi Pembangunan. Jakarta: PT. Pembangunan.

Elyani. 2010. Faktor Yang Mempengaruhi Penenam Modal Asing Berinvestasi di Indonesia.Jurnal: Abdi Ilmu Volume 3 Nomor 1, April 2010.

Iqraam M, Sudibia I.K. 2019. Pengaruh PDRB, Pendidikan, Kesempatan Kerja, dan Persentase Penduduk Sektor Informal terhadap Kemiskinan di Provinsi Bali. E-Jurnal EP Unud, Bali, 2019 Volume 8 Nomor 7 Ed.Desember 2019.

Jhingan, M L. 2012. Ekonomi Pembangunan dan Perencanaan. Jakarta: Rajawali Press. 
Imam, Totok. 2018. Path Analysis menggunakan SPSS dan Excel. Bandung: Penerbit Informatika

Nurmasyitah, Mislinawati. 2017. Upaya Pemerintah Dalam Menanggulangi Kemiskinan. Jurnal pesona dasar Vol. 1 No. 5, April 2017.

Mudrajad Kuncoro. 1997. Ekonomi Pembangunan, Yogyakarta: UPP AMP YKPN.

Muda R, Koleangan R, Kalangi J.B, 2019. Pengaruh Angka Harapan Hidup, Tingkat Pendidikan dan Pengeluaran Perkapita terhadap Pertumbuhan Ekonomi di Sulawesi Utara pada Tahun 2003-2017. Jurnal Berkala IImiah Efisiensi, Manado, 2019, Volume19 Nomor Ed.2019.

Kuncoro, Mudrajat 2018. Metode Kuantitatif Edisi Kelima. Penerbit Sekolah Tinggi Ilmu Manajemen YKPN: Yogyakarta

Sugiyono. 2015. Metode Penelitian Pendidikan (Pendekatan Kuantitatif, Kualitatif dan R\&D). Penerbit CV. Alfabeta: Bandung.

Supriatna, N, Ruhimat M, Kosim. 2006. IImu Pengetahuan Sosial (Geografi, Sejarah, Sosiologi, Ekonomi) untuk Kelas VIII Sekolah Menengah Pertama. Bandung: Grafindo Media Pratama.

Sutrisna, I Ketut. 2017. Pengaruh Produksi Dan Inflasi Terhadap Ekspor Dan Pertumbuhan Ekonomi Di Indonesia. E-Jurnal EP Unud, Bali.

Suparmoko. 2002. Publik untuk Keuangan. Semarang: UNDIP

Simanjuntak, Payaman J. 1985. Pengantar Ekonomi Sumber Daya Manusia. Jakarta: Lembaga Penerbit Fakultas Ekonomi Universitas Indonesia.

Sukirno, Sadono. 2000. Makroekonomi Modern: Perkembangan Pemikiran Dari Klasik Hingga Keynesian Baru. Raja Grafindo Pustaka: Jakarta

Samuelson, Paul A. dan William D Nordhaus. 1997. Pengantar Teori Ekonomi. Jakarta: Erlangga

Rakhmawati, Atifatur. Boedirochminarni, Arfida. 2018. Analisis Tingkat Penyerapan Tenaga Kerja Sektor Industri Di Kabupaten Gresik. Jurnal Ilmu Ekonomi. 
Andi Lopa Ginting. Dampak Angka Harapan Hidup...

Ratih, Gusti Ayu P. Ambara. 2017. Pengaruh Investasi, Pengeluaran Pemerintah, Tenaga Kerja terhadap PDRB dan Tingkat Kemiskinan pada Wilayah Sarbagita di Provinsi Bali. EJurnal EP Unud, Bali, 2017, Volume 6 Nomor 2 Ed.2017.

Todaro, Michael P. and Smith, Stephen C. 2006. Pembangunan Ekonomi, Edisi Terjemahan, Edisi Kesembilan, Jilid 1, Penerbit Erlangga, Jakarta. Vol 2 Jilid 1/Tahun 2018. 